\title{
PENGEMBANGAN MODEL PEMBELAJARAN MATEMATIKA BERBASIS MASALAH UNTUK SISWA SMP
}

\author{
Uki Rahmawati ${ }^{1)}$, Suryanto ${ }^{2)}$ \\ Universitas Mercu Buana Yogyakarta ${ }^{1)}$, Universitas Negeri Yogyakarta ${ }^{2)}$ \\ uki.rahmawati@gmail.com ${ }^{1)}$, suryauny@yahoo.com ${ }^{2)}$
}

\begin{abstract}
Abstrak
Penelitian ini bertujuan untuk menghasilkan model pembelajaran matematika berbasis masalah yang valid, praktis, dan efektif untuk siswa SMP kelas VIII semester 2. Tahap-tahap pengembangan model pembelajaran matematika berbasis masalah terdiri atas (1) tahap pendahuluan, (2) tahap prototiping yang meliputi perencanaan, evaluasi dan revisi, dan (3) tahap penilaian produk. Kualitas model pembelajaran matematika berbasis masalah mengacu pada kriteria kualitas menurut Nieveen yaitu meliputi kriteria valid, praktis, dan efektif. Pembelajaran matematika berbasis masalah diujicobakan di SMP Negeri 15 Yogyakarta dengan melibatkan 33 siswa dan seorang guru matematika. Instrumen dalam penelitian ini terdiri atas (1) instrumen penilaian kevalidan komponen model dan perangkat pendukung pembelajaran, (2) instrumen penilaian kepraktisan dari guru dan siswa, dan (3) instrumen keefektifan yang meliputi lembar tes hasil belajar dan angket apresiasi siswa terhadap pembelajaran matematika berbasis masalah. Hasil penelitian menunjukkan bahwa model pembelajaran matematika berbasis masalah yang mencakup sintak/langkah-langkah pembelajaran, sistem sosial, prinsip reaksi, sistem pendukung dan dampak instruksional dan pendukung, beserta perangkat pendukung pembelajaran telah memenuhi kriteria valid, praktis, dan efektif.
\end{abstract}

Kata kunci: pengembangan, model pembelajaran, pembelajaran matematika berbasis masalah

\section{DEVELOPING A PROBLEM-BASED MATHEMATICS INSTRUCTION MODEL FOR STUDENTS OF JUNIOR HIGH SCHOOL}

\begin{abstract}
This study aims to develop a valid, practical, and effective problem-based mathematics instruction model for the second semester of eleventh grade students of junior high school. The development of the instructional model consisted of the stages of a (1) preliminary study, (2) prototyping stage consists of designing, evaluating and revising stage, and (3) product assessment. The aspects of the developed product quality were based on Nieveen's product quality, consisting of 3 criteria, i.e. validity, practicality, and effectiveness. The tryout research subjects comprised 33 students and one teacher of SMP Negeri 15 Yogyakarta. The research instruments were to assess: (1) validity, consisting of the validators' assessment on components of instruction model and learning kit; (2) practicality, consisting of an evaluation sheet for teachers, and a questionnaire for students, and (3) effectiveness: a learning achievement test, and a questionnaire for students' appreciation for instructional model. The results of the research show that the developed instructional model consisting of syntax, social system, principles of reaction and instructional and nurturant effects including learning kit was in the valid, practical and effective category.
\end{abstract}

Keywords: development, instructional model, mathematics problem-based instruction 


\section{PENDAHULUAN}

Pembelajaran merupakan suatu konstruksi pengetahuan. Hal tersebut sesuai dengan pendapat pendapat Joyce, Weil \& Calhoun (2004, p.13) yaitu "...the idea that learning is the construction of knowledge". Dengan demikian, idealnya proses pembelajaran, khususnya pembelajaran matematika memungkinkan siswa untuk memperoleh pengalaman pembelajaran yang dalam rangka untuk dapat mengkonstruksi pengetahuannya sendiri.

Dalam proses pembelajaran matematika terdapat beberapa komponen-komponen yang dapat mempengaruhi pencapaian tujuan pembelajaran. Komponen-komponen tersebut antara lain langkah-langkah pembelajaran, peran guru dan siswa dalam pembelajaran, cara guru memberikan respon dalam pembelajaran dan sistem pendukung pembelajaran. Komponen-komponen tersebut tercakup dalam istilah model pembelajaran. Gunter, Estes \& Schwab (1990, p.67) menyatakan bahwa "an instructional model is a step-by-step procedure that leads to specific learning outcomes." Artinya model pembelajaran merupakan sebuah prosedur langkah demi langkah yang membawa pada hasil belajar yang spesifik. Dengan demikian, model pembelajaran memeiliki peranan penting dalam pembelajaran, karena mengarahkan kepada pencapaian tujuan pembelajaran.

Dalam Peraturan Menteri Nomor 22 Tahun 2006 tentang Standar Isi, dijelaskan kemampuan pemecahan masalah merupakan salah satu tujuan dalam pembelajaran matematika. Dalam NCTM (2000, p.29) juga dikemukakan bahwa kemampuan pemecahan masalah merupakan bagian dari standard proses dalam pembelajaran matematika. Demikian pentingnya pemecahan masalah dalam pembelajaran matematiika, lebih lanjut dalam Standar Isi juga dijelaskan bahwa pemecahan masalah menjadi fokus dalam pembelajaran matematika.

Berkaca pada kemampuan pemecahan masalah matematis pelajar tingkat SMP di Indonesia, hasil kajian studi TIMSS 2011 menunjukkan hasil yang perlu untuk diperhatikan, yaitu Indonesia berada pada ranking 38 dari 45 negara. Selain itu, dari hasil studi PISA 2009, persentase pelajar tingkat SMP di Indonesia yang telah mencapai kemampuan untuk mengkonseptualisasi, menggeneralisasi dan menggunakan informasi untuk melakukan investigasi dan memodelkan suatu permasalahan yang kompleks, masih mendekati nol. Selanjutnya, didukung dengan hasil kajian program BERMUTU (Better Education through Reformed Management and Universal Teacher Upgrading) yang dilakukan oleh BSNP tahun 2007 menunjukkan bahwa instrumen penilaian yang disusun guru matematika substansinya kurang dikaitkan dengan konteks kehidupan yang dihadapi siswa dan kurang memfasilitasi siswa dalam mengungkapkan proses berpikir dan berargumentasi.

Selanjutnya, berdasarkan hasil kajian terhadap persentase penguasaan soal matematika Ujian Nasional tingkat SMP dari Tahun 20102012 diperoleh suatu kenyataan bahwa pada sebagian besar kompetensi matematika yang tercakup dalam mata pelajaran matematika kelas VIII SMP semester 2 memiliki persentase kurang dari $75 \%$. Beberapa hal tersebut di atas menjadikan suatu ide akan perlunya upaya pengembangan pembelajaran matematika.

Peraturan Menteri Pendidikan Nasional Nomor 41 Tahun 2007 tentang Standar Proses juga mengisyaratkan agar proses pembelajaran perlu direncanakan, dilaksanakan, dinilai, dan diawasi agar terlaksana secara efektif dan efisien. Dengan demikian pengembangan pembelajaran senantiasa perlu untuk terus dilakukan dalam rangka untuk mencapai tujuan pembelajaran. Pembelajaran yang dimaksudkan dalam penelitian ini sesuai dengan pembelajaran yang dimaksudkan dalam Standar Isi, yaitu pembelajaran matematika yang melibatkan masalah kontekstual dalam proses pembelajaraan berfokus pada pendekatan pemecahan masalah.

Posamentier \& Krulik (1998, p.1) memberikan definisi tantang masalah yaitu "a problem is a situation that confronts a person, that requires resolution, and for which the path to the solution is not immediately known". Sejalan dengan pendapat tersebut, Zeits $(2007$, p.1) menyatakan bahwa "a problem demands much thought and resourcefulness before the right approach is found". Suatu permasalahan memerlukan pemikiran dan sumber-sumber yang cukup sebelum diperoleh pendekatan atau cara yang tepat. Dengan demikian dapat disimpulkan bahwa suatu pertanyaan merupakan suatu masalah bagi siswa jika siswa tidak dapat menjawab pertanyaan tersebut dengan menggunakan prosedur rutin yang telah diketahuinya.

Selanjutnya, Arends (2010, p.328) menyatakan bahwa "real-world problems capture students' interest and are motivating". Hal tersebut dapat dimaknai bahwa pertanyaan yang berkaitan dengan kehidupan sehari-hari siswa akan dapat membuat siswa tertarik dan memo- 
tivasi siswa untuk memecahkannya. Jadi, dalam pembelajaran matematika, masalah yang berkaitan dengan kehidupan sehari-hari siswa hendaknya disajikan dalam pembelajaran untuk dapat dipecahkan oleh siswa.

Krulik \& Rudnick (1995, p.4) memberikan deskripsi tentang pemecahan masalah yaitu problem solving merupakan suatu proses dimana siswa dapat menggunakan pengetahuan yang telah diperoleh sebelumnya, keterampilan, dan pemahaman untuk memenuhi tuntutan dari suatu kondisi yang tidak biasa. Lebih lanjut, proses pemecahan masalah matematis meliputi beberapa tahap yaitu (1) tahap memahami masalah, (2) merencanakan strategi, (3) melaksanakan strategi, dan (4) menelaah kembali solusi yang diperoleh (Polya, 1973, p.5).

Pembelajaran berbasis masalah merupakan suatu model pembelajaran pembelajaran yang terstruktur yang dapat membantu siswa untuk dapat membangun pengetahuan dan kemampuan pemecahan masalah serta membantu siswa untuk dapat menguasai pengetahuan (Delisle, 1997, p.6). Dalam pelaksanaanya, pembelajaran berbasis masalah menjadikan masalah kontekstual sebagai awal dari proses pembelajaran. Barrett (2005, p.13) mengemukakan bahwa pemberian masalah pada awal proses pembelajaran merupakan karakteristik utama dari pembelajaran berbasis masalah. Arends (1997, p.157) antara lain yaitu: (1) deriving question or problem, (2) interdisciplinary focus, (3) autenthic investigation, (4) production of artifacs and exhibits (5) collaboration. Lebih lanjut, Arends \& Kilcher (2010, p.326) menambahkan satu fitur dalam pembelajaran berbasis masalah yaitu (6) problem solving. Masalah yang disajikan dalam pembelajaran berbasis masalah berkaitan dengan kehidupan sehari-hari siswa, bermakna dan bersifat kompleks atau menghindari jawaban yang sederhana. Dalam pembelajaran berbasis masalah, pengetahuan yang diperlukan dalam proses investigasi juga mencakup berbagai pengetahuan dalam bidang lain yang telah dimiliki siswa sebelumnya. Selanjutnya dalam melakukan proses penyelidikan untuk dapat menemukan solusi, siswa perlu untuk menganalisis dan mendefinisikan masalah, mengembangkan hipotesis dan membuat prediksi, mengumpulkan dan menganalisis informasi, melakukan percobaan (jika diperlukan), serta membuat kesimpulan. Selanjutnya, PBL juga mengharuskan siswa untuk menghasilkan suatu produk (artifacts) untuk selanjutnya disajikan pada siswa lain. Hal lain yang tidak ketinggalan dalam PBL yaitu kolaborasi. Dalam PBL, proses investigasi dan pemecahan masalah yang dilakukan oleh siswa dilaksanakan bersama satu teman atau dalam kelompok kecil.

Selanjutnya, pembelajaran berbasis masalah juga memiliki beberapa keunggulan, salah satunya yaitu dapat membantu meningkatkan prestasi dan kemampuan berpikir tingkat tinggi (Arends \& Kilcher, 2010, p.328). Selanjutnya, berdasarkan kajian penelitian yang telah dilakukan oleh Kohlhaas (2011), dan Smith \& Cook (2012) menunjukkan bahwa pembelajaran berbasis masalah mampu meningkatkan prestasi belajar. Dengan demikian, pembelajaran berbasis masalah dapat menjadi suatu pilihan dalam pembelajaran matematika yang memiliki kesempatan yang besar untuk mencapai tujuan pembelajaran matematika

Sesuai dengan penjelasan di atas, dalam pembelajaran matematika senantiasa perlu untuk dilakukan pengembangan. Dengan demikian dalam penelitian ini, akan dikembangkan model pembelajaran matematika berbasis masalah dengan tujuan untuk dapat menghasilkan suatu model pembelajaran matematika berbasis masalah yang mencakup sintak, sistem sosial, prinsip reaksi, sistem pendukung, dan dampak instruksional dan pengiring yang memenuhi kriteria valid, praktis, dan efektif yang dapat diterapkan dalam pembelajaran di sekolah.

\section{METODE PENELITIAN}

\section{Jenis Penelitian}

Penelitian ini merupakan penelitian pengembangan. Model pengembangan yang digunakan dalam penelitian ini mengacu pada tahap pengembangan menurut Nieveen yang meliputi (1) preliminary stage (tahap pendahuluan), (2) prototyping stage (tahap prototiping), (3) assessment stage (tahap penilaian) (Nieveen, McKenney \& Akker, 2006, p.154). Selanjutnya, kualitas model pembelajaran matematika berbasis masalah juga mengacu pada kriteria kualitas menurut Nieveen meliputi kriteria valid, praktis, dan efektif (Nieveen, 1999, p.127)

\section{Waktu dan Tempat Penelitian}

Uji coba model pembelajaran matematika berbasis masalah dilakukan di SMP Negeri 15 Yogyakarta pada tanggal 11 April 2013-14 Mei 2013. 


\section{Target/Subjek Penelitian}

Dalam pengembangan model matematika berbasis masalah ini melibatkan tiga orang ahli yaitu dosen dari jurusan pendidikan matematika untuk menentukan kevalidan model pembelajaran. Selanjutnya, pada tahap uji coba model pembelajaran matematika berbasis masalah melibatkan 33 siswa kelas VIIIC dan seorang guru matematika SMP Negeri 15 Yogyakarta.

\section{Prosedur}

Prosedur pengembangan model pembelajaran matematika berbasis masalah terdiri atas tahap (1) preliminary stage (tahap pendahuluan), (2) prototyping stage (tahap prototiping), (3) assessment stage (tahap penilaian).

Pada tahap pendahuluan dilakukan studi pendahuluan, kajian terhadap penelitian-penelitian terkait, dan kajian literatur. Studi pendahuluan dilakukan dengan memberikan angket pada guru matematika pada beberapa sekolah di Yogyakarta, dan melakukan observasi pembelajaran matematika di sekolah. Selanjutnya hasil yang diperoleh pada tahap pendahuluan ini akan digunakan untuk merancang model pembelajaran yang dikembangkan.

Pada tahap prototiping, direncanakan komponen-komponen model pembelajaran (sintak, sistem sosial, prinsip reaksi, sistem pendukung, dan dampak instruksional dan pengiring), perangkat pendukung pembelajaran, dan instrumen untuk menilai kualitas model pembelajaran yang dikembangkan. Selanjutnya hasil perencanaan model pembelajaran, perangkat pendukung pembelajaran dan instrumen penilaian kualitas model pembelajaran dinilai oleh ahli untuk dinilai kevalidannya. Selanjutnya pada model pembelajaran dari hasil penilaian ahli dilakukan revisi jika diperlukan. Model pembelajaran yang valid selanjutnya dapat diujicobakan di sekolah untuk dapat diketahui kepraktisan dan keefektifannya.

Pada tahap assessment, model pembelajaran yang telah memenuhi kriteria valid diujicobakan dalam proses pembelajaran matematika di sekolah. Selanjutnya model pembelajaran tersebut dinilai kepraktisannya oleh guru dan siswa. Selanjutnya, untuk mengetahui keefektifan model pembelajaran, siswa diberikan tes hasil belajar. Selanjutnya keefektifan model pembelajaran ditentukan oleh hasil belajar dan apresiasi siswa terhadap pembelajaran matematika berbasis masalah.

\section{Data, Instrumen, dan Teknik Pengumpulan Data}

Data dalam penelitian ini terdiri atas data kuantitatif dan kualitatif. Data kuantitatif diperoleh dari hasil lembar penilaian kevalidan oleh ahli, lembar penilaian kepraktisan dari guru dan siswa, dan hasil tes hasil belajar. Sedangkan kualitatif berupa masukan dan saran baik dari ahli, guru, atau siswa sebagai bahan perbaikan model pembelajaran.

\section{Instrumen}

Instumen yang digunakan dalam penelitian ini terdiri atas (1) instrumen kevalidan yaitu meliputi (a) lembar penilaian kevalidan komponen model pembelajaran, dan (b) lembar penilaian perangkat pendukung pembelajaran (RPP, LKS, THB); (2) instrumen penalian kepraktisan yaitu meliputi (a) lembar penilaian dari guru, dan (b) angket penilaian dari siswa; dan (3) instrumen penilaian keefektifan yaitu meliputi (a) lembar tes hasi belajar, dan (b) angket apresiasi siswa terhadap pembelajaran matematika berbasis masalah.

\section{Teknik Analisis Data}

Kevalidan model pembelajaran matematika berbasis masalah ditentukan oleh penilaian ahli. Skor yang diperoleh dari lembar penilaian kevalidan, kepraktisan dan keefektifan model pembelajaran dikonversikan ke dalam kategorisasi kualitatif, dengan mengacu kategorisasi kualitatif menurut Azwar (2010, p.163) pada Tabel 1.

Model pembelajaran dikatakan valid jika minimal penilaian ahli terhadap komponen model pembelajaran dan perangkat pendukung pembelajaran mencapai kriteria valid. Selanjutnya, model pembelajaran matematika berbasis masalah dikatakan praktis, jika hasil penilaian guru dan siswa minimal mencapai kriteri praktis. Keefektifan pembelajaran ditentukan oleh hasil belajar dan tingkat apresiasi siswa terhadap pembelajaran matematika berbasis masalah. Model pembelajaran matematika berbasis masalah dikatakan efektif jika hasil ketuntasan belajar klasikal minimal sebesar 75\% dengan KKM 75. Selain itu, model pembelajaran matematika berbasis masalah dikatakan efektif jika tingkat apresiasi siswa terhadap pembelajaran matematika berbasis masalah minimal mencapai kriteria efektif. 
Tabel 1. Kriteria Konversi Data Kuantitatif ke Data Kualitatif

\begin{tabular}{|c|c|c|}
\hline Interval Skor & Nilai & Kategori \\
\hline$M_{\mathrm{i}}+1,5 \mathrm{SB}_{\mathrm{i}}<\mathrm{X} \leq M_{\mathrm{i}}+3 \mathrm{SB}_{\mathrm{i}}$ & A & $\begin{array}{c}\text { Sangat } \\
\text { Baik }\end{array}$ \\
\hline $\begin{array}{c}M_{\mathrm{i}}+0,5 \mathrm{SB}_{\mathrm{i}}<\mathrm{X} \leq M_{\mathrm{i}}+1,5 \\
\mathrm{SB}_{\mathrm{i}}\end{array}$ & B & Baik \\
\hline $\begin{array}{c}M_{\mathrm{i}}-0,5 \mathrm{SB}_{\mathrm{i}}<\mathrm{X} \leq M_{\mathrm{i}}+0,5 \\
\mathrm{SB}_{\mathrm{i}}\end{array}$ & $\mathrm{C}$ & $\begin{array}{l}\text { Cukup } \\
\text { Baik }\end{array}$ \\
\hline $\begin{array}{c}M_{\mathrm{i}}-1,5 \mathrm{SB}_{\mathrm{i}}<\mathrm{X} \leq M_{\mathrm{i}}-0,5 \\
\mathrm{SB}_{\mathrm{i}}\end{array}$ & $\mathrm{D}$ & $\begin{array}{l}\text { Kurang } \\
\text { Baik }\end{array}$ \\
\hline$M_{\mathrm{i}}-3 \mathrm{SB}_{\mathrm{i}}<\mathrm{X} \leq M_{\mathrm{i}}-1,5 \mathrm{SB}_{\mathrm{i}}$ & $\mathrm{E}$ & $\begin{array}{c}\text { Tidak } \\
\text { Baik }\end{array}$ \\
\hline
\end{tabular}

\section{HASIL PENELITIAN DAN PEMBAHASAN}

Pembelajaran yang dikembangkan dalam penelitian ini yaitu pembelajaran matematika berbasis masalah yang terdiri atas sintak/langkah pembelajaran, sistem sosial, prinsip reaksi, sistem sosial, dan dampak instruksional dan pengiring. Berikut hasil yang diperoleh dari penelitian pengembangan ini.

Berdasarkan hasil penilaian ahli terhadap kevalidan model pembelajaran matematika berbasis masalah, dapat ditunjukkan bahwa komponen-komponen pembelajaran matematika berbasis masalah mencapai kriteria sangat valid. Hasil penilaian ahli terhadap komponen model pembelajaran matematika berbasis masalah dapat dilihat pada Tabel 2 berikut.

Tabel 2. Skor dan Kriteria Hasil Penilaian

Kevalidan Model Pembelajaran Matematika Berbasis Masalah

\begin{tabular}{cccc}
\hline No & Komponen & $\begin{array}{c}\text { Rata- } \\
\text { Rata } \\
\text { skor }\end{array}$ & Kriteria \\
\hline 1 & Sintak & 12,5 & Sangat Valid \\
2 & Sistem Sosial & 13 & Sangat Valid \\
3 & Prinsip Reaksi & 8 & Sangat Valid \\
4 & $\begin{array}{c}\text { Dampak Pengiring } \\
\text { \& Instruksional }\end{array}$ & 8 & Sangat Valid \\
\hline
\end{tabular}

Selanjutnya, hasil penilaian kevalidan perangkat pendukung pembelajaran secara ringkas dapat dilihat pada Tabel 3 berikut.

Tabel 3. Skor dan Kriteria Hasil Penilaian Kevalidan Perangkat Pembelajaran Matematika Berbasis Masalah

\begin{tabular}{ccc}
\hline Produk & Rata-Rata Skor & Kriteria \\
\hline RPP & 70,25 & Sangat valid \\
LKS & 60 & Sangat valid \\
THB & & Valid \\
\hline
\end{tabular}

Berdasarkan Tabel 3 di atas dapat ditunjukkan bahwa perangkat pendukung pembelajaran matematika berbasis masalah yang mencakup RPP, LKS dan THB telah memenuhi kriteria valid. Dengan demikian, model pembelajaran matematika berbasis masalah telah memenuhi kriteria valid.

Komponen-komponen pembelajaran matematika berbasis masalah yang telah memenuhi kriteria valid terdiri atas sitak, sistem sosial, prinsip reaksi, sistem pendukung, dan dampak instruksional dan pendukung. Sintak pembelajaran matematika berbasis masalah terdiri atas (1) orientasi siswa pada situasi masalah. Pada fase ini, secara umum guru berperan untuk menyajikan masalah dan membimbing siswa untuk dapat menggali informasi apa saja yang diketahui tentang masalah, menghasilkan daftar pertanyaan dan merekam pemikiran awal dan hipotesis tentang masalah. Selama hasil uji coba model pembelajaran di sekolah yaitu selama delapan kali pertemuan, tahap orientasi pada masalah dalam pembelajaran matematika dapat terlaksana pada keseluruhan pertemuan; (2) organisasi siswa untuk belajar, pada tahap ini, aktivitas difokuskan pada pengkondisian siswa untuk belajar dalam kelompok, dimana kelompok belajar siswa telah tentukan oleh guru. Pada tahap ini siswa juga dituntut untuk dapat menentukan sumber belajar yang dapat digunakan untuk dapat menyelesaikan masalah. Pada pertemuan pertama, persentase keterlaksanaan tahap orientasi siswa untuk belajar yaitu sebesar $67 \%$. Hal tersebut dapat disebabkan siswa belum terbiasa untuk belajar secara berkelompok dengan anggota kelompok yang telah ditentukan oleh guru. Selain itu, hal lain yang mungkin menjadi sebab yaitu siswa belum terbiasa dan belum siap untuk menentukan sumber belajar secara mandiri. Namun demikian, pada pertemuan-pertemuan selanjutnya tahap organisasi siswa untuk belajar dapat terlaksana dengan baik yang ditunjukkan dengan persentase keterlaksanaan mencapai 100. Pada pertemuan ketujuh dan kedelapan persentase keterlaksanaan langkah ketujuh dan kedelapan mengalami penurunan yaitu $67 \%$. Berdasarkan informasi yang diperoleh dari guru, hal tersebut dimungkinkan karena siswa merasa bosan dengan rekan anggota kelompoknya mulai dari pertemuan pertama hingga terakhir; (3) penyelesaian masalah, proses pemecahan masalah yang dilakukan siswa difokuskan pada keempat tahap penyelesaian masalah menurut Polya, yaitu terdiri atas tahap (a) memahami masalah, (b) merencanakan strategi, (c) 
melaksanakan strategi, dan (d) menelaah ulang solusi yang diperoleh. Berdasarkan hasil observasi keterlaksanaan sintak pembelajaran matematika berbasis masalah, dapat diperoleh informasi bahwa tahap pemecahan masalah pada awal pembelajaran hingga pertemuan keenam dapat terlaksana secara $100 \%$. Pada pertemuan ketujuh dan kedelapan tahap pemecahan masalah hanya dapat terlaksana secara $50 \%$, hal tersebut dimungkinkan oleh kendala jenis kompetensi dan tingkat kesulitan soal yang disajikan yaitu mengenai volum prisma dan limas; (4) penyajian hasil karya, pada tahap penyajian hasil karya, beberapa perwakilan kelompok siswa menyajikan hasil investigasi mereka pada guru dan seluruh siswa. Selanjutnya, guru memberikan kesempatan kepada kelompok lain untuk menanggapi hasil presentasi kelompok tersebut. Selain itu tugas guru juga memberikan feedback dan reward atas hasil dan presentasi siswa. Berdasarkan hasil observasi pada pelaksanaan pembelajaran matematika berbasis masalah, pada awalnya tahap penyajian hasil karya belum dapat terlaksana secara baik, hal tersebut ditunjukkan dengan persentase keterlaksanaan tahap penyajian hasil karya pada pertemuan pertama hanya sebesar $50 \%$. Hal tersebut disebabkan oleh belum terbiasanya siswa untuk mempresentasikan hasil karya atau pemecahan masalah saat pembelajaran. Namun demikian, tahap presentasi karya oleh siswa pada pertemuan-pertemuan selanjutnya dapat terlaksana dengan persentase 100\%; dan (5) analisis dan evaluasi, pada tahap ini guru bersama dengan siswa melakukan refleksi atau evaluasi terhadap proses pemecahan masalah yang telah dilakukan siswa. Tahap ini membantu siswa untuk merefleksikan pengetahuan dan keterampilan yang telah mereka peroleh, strategi pembelajaran yang siswa gunakan, dan kontribusi siswa dalam pembelajaran kelompok. Seperti hanya keterlaksanaan tahap penyajian karya oleh siswa, tahap analisis dan evaluasi proses pembelajaran pada awalnya hanya dapat mencapai 50\%. Namun demikian, pada pertemuan kedua hingga terakhir, tahap analisis dan evaluasi dapat terlaksana secara $100 \%$.

Sistem sosial dalam pembelajaran matematika berbasis masalah ini mencakup peran dan hubungan siswa dan guru secara rinci pada setiap tahap pembelajaran. Sistem sosial pada tahap orientasi masalah dan organisasi siswa untuk belajar adalah sangat terstruktur dan dikendalikan oleh guru. Pada tahap penyelesaian masalah secara individual atau kelompok, siswa berperan besar dalam aktivitas pembelajaran khususnya aktivitas dalam kelompoknya, sedangkan guru berperan sebagai fasilitator dan pembimbing. Berdasarkan analisis keterlaksanaan model pembelajaran berbasis masalah dapat diketahui bahwa pada keseluruhan pembelajaran matematika berbasis masalah guru telah berperan sebagai fasilitator dan pembimbing yaitu dengan cara mengondisikan siswa untuk belajar, membantu siswa untuk mendefinisikan dan mengorganisasikan tugas belajar, dan mendorong siswa untuk mengumpulkan informasi untuk memperoleh penyelesaian masalah. Pada tahap penyajian hasil karya, sistem sosial sangat demokratis, sepenuhnya dikendalikan oleh siswa. Berdasarkan analisis keterlaksanaan model pembelajaran matematika berbasis masalah, siswa telah mulai terlibat dalam pemecahan masalahnya mulai dari pertemuan kedua hingga keenam. Selanjutnya peran guru sebagai evaluator juga telah terlaksana pada keseluruhan pembelajaran matematika berbasis masalah selama delapan kali pertemuan.

Prinsip reaksi berkaitan dengan peran guru dalam pembelajaran. Dalam pembelajaran matematika berbasis masalah guru berperan untuk mengarahkan dan menekankan proses pemecahan masalah, serta memberikan umpan balik terhadap hasil penyelesaian masalah matematis siswa. Peran guru untuk mengevaluasi dan membimbing siswa selama proses pembelajaran telah dapat terlaksana selama delapan kali pembelajaran matematika berbasis masalah di sekolah.

Sistem pendukung yang diperlukan untuk dapat melaksanakan model pembelajaran matematika berbasis masalah adalah Lembar Kegiatan Siswa (LKS) untuk menunjang pembelajaran matematika berbasis masalah, serta beberapa alat peraga (misal model bangun ruang) dalam pelaksanaan pembelajaran matematika pada materi geometri. Dalam implementasi pembelajaran matematika berbasis masalah di sekolah, sistem pendukung berupa LKS yang menstimulasi kemampuan pemecahan masalah dan alat peraga berupa model bangun ruang telah tersedia pada keseluruhan pertemuan pembelajaran.

Selanjutnya, komponen terakhir dalam model pembelajaran matematika berbasis masalah yaitu dampak instruksional dan dampak pengiring. Dampak instruksional meliputi: proses pemecahan masalah, penguasaan kompetensi dasar (KD), dan kemampuan mengonstruksi pengetahuan. Ketercapaian kompetensi dasar dapat ditunjukkan dari hasil belajar siswa, se- 
dangkan proses pemecahan masalah juga telah telaksana pada sebagian besar pelaksanaan pembelajaran berdasarkan hasil observasi keterlaksanaan pembelajaran matematika berbasis masalah. Dampak pengiring meliputi: keterampilan kooperatif, kemampuan mengendalikan diri, kepercayaan diri, penghargaan diri, dan memotivasi siswa.

Berdasarkan hasil uji coba model pembelajaran matematika di sekolah, dapat diketahui kepraktisan model pembelajaran matematika berbasis masalah.

Tabel 4. Skor dan Kriteria Hasil Penilaian Kepraktisan Model Pembelajaran Matematika Berbasis Masalah dari Guru

\begin{tabular}{ccc}
\hline Pertemuan & Skor & Kriteria \\
\hline I & 45 & Praktis \\
II & 55 & Sangat Praktis \\
III & 47 & Praktis \\
IV & 52 & Sangat Praktis \\
V & 51 & Sangat Praktis \\
VI & 52 & Sangat Praktis \\
VII & 55 & Sangat Praktis \\
VIII & 50 & Sangat Praktis \\
Skor rata-rata & 50,8 & Sangat Praktis \\
\hline
\end{tabular}

Berdasarkan Tabel 4 di atas, dapat ditunjukkan bahwa keseluruhan pembelajaran yaitu sebanyak delapan kali pembelajaran, guru menyatakan bahwa secara keseluruhan, model pembejaran matematika berbasis masalah yang dikembangkan telah memenuhi kriteria sangat praktis. Namun, dapat diketahui bahwa dari delapan kali pertemuan, sebanyak empat kali pertemuan pembelajaran guru menyatakan tidak setuju dengan kemudahan langkah-langkah pembelajaran matematika berbasis masalah. Hal tersebut dapat dikarenakan guru belum terbiasa dengan model pembelajaran matematika berbasis masalah. Selain itu, waktu yang digunakan guru untuk mempelajari model pembelajaran ini juga cukup singkat, sehingga menyebabkan kurangnya persiapan dari guru yang berdampak pada pelaksanaan implmentasi model di kelas. Selanjutnya, dari segi pengaturan diskusi pada pertemuan pertama guru juga menyatakan tidak setuju terhadap kemudahan pengaturan diskusi di kelas. Hal tersebut dimungkinkan siswa belum terbiasa untuk berdiskusi dengan anggota kelompok yang telah ditentukan oleh guru. Selanjutnya, Pada pertemuan kedelapan, guru juga menyatakan tidak setuju terhadap kemudahan pengaturan diskusi. Hal tersebut disebabkan oleh beberapa siswa telah merasa bosan untuk berdiskusi dengan anggota kelompoknya. Ke- nyataan ini memberikan masukan bagi peneliti untuk memperbaiki dan menambahkan adanya pergantian anggota kelompok pada beberapa pertemuan jika diperlukan. Hal tersebut dilakukan dengan tujuan untuk mengatasi adanya kemungkinan munculnya kejenuhan dari siswa, sehingga diharapkan kegiatan diskusi siswa dapat tetap berjalan dengan lancar.

Hasil penilaian kepraktisan dari siswa juga menunjukkan bahwa model pembelajaran matematika berbasis masalah memenuhi kriteria sangat praktis. Berikut hasil penilaian kepraktisan dari siswa.

Tabel 5. Skor dan Kriteria Hasil Penilaian Kepraktisan dari Siswa

\begin{tabular}{cc}
\hline & TOTAL \\
\hline Skor Aktual & 8,06 \\
Kriteria & Sangat Praktis \\
Persentase Jawaban "ya" & $\mathbf{8 9 , 5 6 \%}$ \\
\hline
\end{tabular}

Berdasarkan hasil uji coba model pembelajaran matematika berbasis masalah di kelas VIIIC SMP Negeri 15 Yogyakarta juga dapat direkam proses pemecahan masalah matematis yang dialami siswa. Tahap-tahap pemecahan masalah matematis selama uji coba model pembelajaran berbasis masalah terdiri atas (1) memahami masalah, (2) merencanakan strategi, (3) melaksanakan strategi, dan (4) menelaah kembali solusi yang diperoleh.

Pada tahap memahami masalah (understand the problem), hal pertama yang harus dipahami siswa untuk dapat menyelesaikan suatu masalah yaitu memahami masalah. Pada tahap memahami masalah siswa harus mengetahui hal yang akan dicari (the unknown), hal yang diketahui (the data) dan keterkaitan antara hal yang akan dicari dan hal yang akan diketahui. Pada awalnya, siswa memerlukan banyak bimbingan dari guru untuk dapat memahami masalah yang disajikan. Hal tersebut terjadi karena dalam pembelajaran matematika yang sebelumnya, siswa belum terbiasa untuk melaksanakan pembelajaran berbasis masalah. Oleh karena itu, guru sering memberikan pertanyaan-pertanyaan yang membantu memunculkan kemampuan siswa untuk memahami masalah, misalnya "hal apa yang diketahui?", "apa yang akan dicari?", "bagaimana kaitan antara data dengan hal yang akan dicari?", "sudah cukupkah data yang kalian miliki untuk dapat menjawab soal?". Pada setiap pertemuan, guru selalu menekankan akan pentingnya memahami masalah (memahami data, hal yang akan dicari dan hubungan data dan pertanyaan) untuk dapat menyelesaikan masalah. 
Namun, kesulitan yang masih ditemui guru yaitu cara membantu siswa untuk menemukan hubungan antara data dengan pertanyaan. Berdasarkan hasil uji coba model yang dilaksanakan, dapat dikatakan bahwa dalam proses pemecahan masalah, khususnya pada tahap memahami masalah, guru sangat berperan penting untuk dapat membimbing siswa dengan cara memberikan petunjuk-petunjuk atau pertanyaan-pertanyaan yang selanjutnya mampu mengarahkan siswa untuk dapat memahami masalah.

Setelah tahap memahami masalah mampu dilalui siswa, maka tahap selanjutnya dalam rangka penyelesaian masalah yaitu tahap merencanakan strategi. Dalam model pembelajaran yang dikembangkan ini, keseluruhan Kompetensi Dasar berada dalam ruang lingkup Geometri. Beberapa strategi pemecahan masalah yang digunakan siswa selama proses pembelajaran matematika dengan model pembelajaran berbasis masalah antara lain yaitu (1) dengan membuat gambar/sketsa bangun ruang, (2) menebak dan memeriksa, dan (3) membuat model matematika.

Dalam proses pemecahan masalah, setelah siswa berhasil menentukan strategi pemecahan masalah yang tepat, maka hal selanjutnya dilakukan siswa adalah melaksanakan stategi tersebut. Selama proses pembelajaran, siswa diberikan kebebasan untuk dapat menentukan dan melaksanakan strategi pemecahan masalah yang ada. Guru dalam hal ini berperan sebagai fasilitator dan sekaligus sebagai evaluator untuk membantu memastikan siswa bahwa langkah yang dilaksanakan siswa sudah tepat.

Selama proses pemecahan masalah berlangsung, guru senantiasa mengingatkan siswa untuk memastikan bahwa jawaban atau penyelesaian yang diperoleh siswa sudah benar dengan cara meminta siswa untuk memeriksa kembali perhitungan dan langkah-langkah yang telah ditempuh siswa. Namun, selama proses uji coba, masih ada saja siswa yang melewatkan tahap menelaah kembali jawaban/penyelesaian masalah.

Meskipun secara kuantitatif hasil penilaian kepraktisan menunjukkan kategori praktis, berdasarkan beberapa saran dan komentar siswa pada angket respon siswa menunjukkan bahwa beberapa siswa mengalami kejenuhan dalam mengikuti proses pembelajaran dalam kelompok. Beberapa hal yang dimungkinkan menjadi penyebab timbulnya rasa bosan pada siswa yaitu tidak adanya pergantian atau rotasi anggota kelompok pada aktivitas pembelajaran, siswa belum terbiasa dengan pembelajaran berkelompok, atau pembagian kelompok yang heterogen menjadikan kinerja kelompok kurang kondusif.

Selanjutnya, data mengenai keefektifan model pembelajaran berbasis masalah ditunjukkan oleh tes hasil belajar siswa dan tingkat apresiasi siswa terhadap model pembelajaran matematika berbasis masalah. Setelah melakukan uji coba model pembelajaran matematika berbasis maslah di sekolah sebanyak delapan kali pertemuan, hasil belajar siswa ditunjukkan pada Tabel berikut.

Tabel 6. Data Hasil Siswa

\begin{tabular}{lll}
\hline No & \multicolumn{1}{c}{ Kategori } & Skor \\
\hline 1 & Nilai Maksimum & 100 \\
2 & Nilai Tertinggi & 100 \\
3 & Nilai Minimal yang dicapai Siswa & 38 \\
4 & Rata-Rata & 82,7 \\
5 & Standar Deviasi & 14,4 \\
\hline
\end{tabular}

Berdasarkan nilai tertinggi yang dicapai siswa pada tes hasil belajar yaitu 100 , sedangkan nilai minimalnya yaitu 38. Selanjutnya, dari 33 siswa yang mengikuti pembelajaran matematika berbasis masalah, terdapat 25 siswa yang telah mencapai kriteria tuntas. Dengan demikian dari hasil tes, persentase ketuntasan hasil belajar secara klasikal telah memenuhi kriteria efektif. Berikut ditunjukkan persentase ketuntasan klasikal yang dicapai siswa.

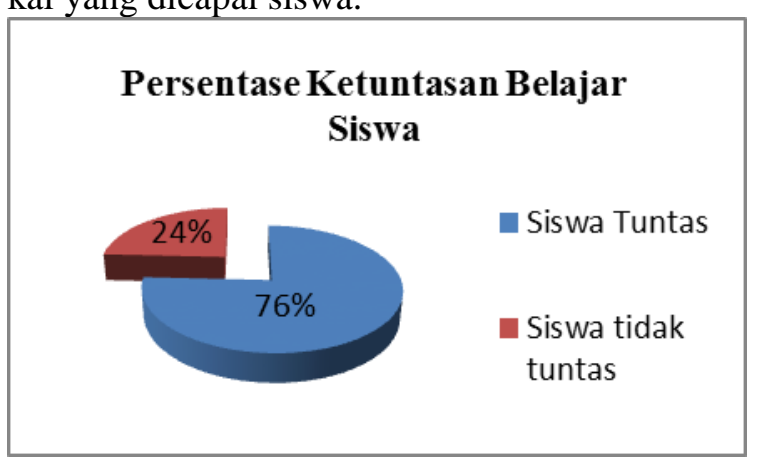

Gambar 1. Persentase Ketuntasan Belajar Siswa

Selanjutnya, data hasil angket apresiasi siswa terhadap pembelajaran matematika berbasis masalah juga menunjukkan bahwa apresiasi siswa terhadap pembelajaran telah mencapai kriteria efektif. Dengan demikian dapat dikatakan bahwa model pembelajaran matematika berbasis masalah telah memenuhi kriteria efektif.

Selain itu, berdasarkan hasil analisis korelasi antara apresiasi siswa terhadap pembelajaran matematika berbasis masalah dengan hasil belajar siswa, dapat diperoleh nilai koefisien 
korelasi yaitu $r=0,705$. Berdasarkan hasil uji signifikansi koefisien korelasi dapat disimpulkan bahwa terdapat korelasi positif antara apresiasi siswa terhadap pembelajaran.

Berdasarkan semua kajian di atas dapat dinyatakan bahwa pengembangan pembelajaran matematika berbasis masalah merupakan suatu pembelajaran yang telah teruji kevalidan, kepraktisan dan keefektifannya, sehingga dapat dipertimbangkan untuk dapat digunakan pada pembelajaran matematika di sekolah.

\section{SIMPULAN DAN SARAN}

\section{Simpulan}

Berdasarkan tahap-tahap pengembangan yang telah dilakukan, telah dihasilkan model pembelajaran berbasis masalah. Model Pembelajaran Matematika Berbasis Masalah yang memenuhi kriteria valid, praktis, dan efektif terdiri atas komponen-komponen (1) sintak pembelajaran matematika berbasis masalah terdiri atas langkah-langkah yaitu (a) orientasi siswa pada suatu masalah, (b) organisasi siswa untuk belajar, (c) penyelesaian masalah matematis yang meliputi tahap memahami masalah, merencanakan strategi, melaksanakan strategi, dan menelaah kembali solusi yang diperoleh, (d) penyajian hasil karya, dan (e) analisis dan evaluasi; (2) sistem sosial dalam pembelajaran matematika berbasis masalah yaitu guru berperan sebagai fasilitator dan evaluator proses pemecahan masalah matematis, pembelajaran berpusat pada proses pemecahan masalah matematis oleh siswa dan bersifat demokratis bagi siswa untuk mengemukakan gagasan/hasil pemecahan masalahnya; (3) prinsip reaksi dalam pembelajaran matematika berbasis masalah yaitu guru membimbing dan menekankan pada proses pemecahan masalah matematis oleh siswa, serta guru mengevaluasi dan memberikan umpan balik terhadap hasil pemecahan masalah matematis siswa; (4) sistem pendukung pembelajaran matematika berbasis masalah yaitu masalah kontekstual dan berkaitan dengan kehidupan sehari-hari siswa yang tercakup dalam LKS, ketersediaan sumber belajar dan alat peraga misalnya berupa model bangun ruang bagi siswa; (5) dampak instruksional pembelajaran matematika berbasis masalah yaitu ketercapaian kompetensi dan proses pemecahan masalah matematis, sedangkan dampak pengiringnya yaitu ketrampilan untuk bekerjasama, kepercayaan diri, kemampuan untuk mengendalikan diri, dan memotivasi.
Kevalidan model pembelajaran matematika berbasis masalah berdasarkan penilaian ahli yaitu (1) sintak, sistem sosial, prinsip reaksi, dan dampak instruksional dan pengiring telah mencapai kriteria sangat valid; (2) perangkat pembelajaran berupa RPP dan LKS mencapai kriteria sangat valid, serta THB mencapai kriteria valid. Kepraktisan model pembelajaran matematika berbasis masalah berdasarkan (1) penilaian dari guru telah mencapai kriteria sangat praktis; (2) penilaian dari siswa telah dicapai kriteria sangat praktis. Keefektifan model pembelajaran matematika berbasis masalah berdasarkan (1) hasil THB siswa, telah memenuhi syarat keefektifan dengan persentase ketuntasan $76 \%$, (b) apresiasi siswa terhadap pembelajaran matematika berbasis masalah yang mencapai kriteria baik. Selain itu juga dapat dikatakan bahwa terdapat korelasi positif antara apresiasi siswa terhadap pembelajaran matematika berbasis masalah dengan hasil belajar matematika pada taraf signifikansi 5\% dengan koefisien korelasi $r$ $=0,705$.

\section{Saran}

Model pembelajaran matematika berbasis masalah yang telah dikembangkan telah memenuhi kualitas yaitu memenuhi kriteria valid, praktis, dan efektif, sehingga bagi guru SMP, disarankan untuk memanfaatkan produk pembelajaran matematika yang dikembangkan sebagai salah satu pembelajaran matematika yang diharapkan mampu menstimulasi proses pemecahan masalah matematis. Selanjutnya pelaksanaan pembelajaran matematika di sekolah hendaknya senantiasa disesuaikan dan didasarkan pada kurikulum yang telah ditentukan oleh Pemerintah.

Dalam penelitian ini pembelajaran yang dikembangkan hanya terbatas pada materi geometri pada pembelajaran matematika SMP kelas VIII semester 2 yaitu meliputi lingkaran dan bangun ruang sisi datar, maka disarankan kepada peneliti lain untuk mengembangkannya pada ruang lingkup materi yang lain atau pada tingkat satuan pendidikan yang berbeda.

Berdasarkan hasil penelitian dapat diketahui bahwa apresiasi siswa terhadap pembelajaran memiliki korelasi positif dengan hasil belajar siswa, sehingga penting untuk diperhatikan bahwa sebaiknya proses pembelajaran mampu membangkitkan dan meningkatkan apresiasi siswa yang mencakup aspek perhatian, kesenangan, partisipasi dan ketertarikan untuk dapat membantu siswa memperoleh hasil belajar yang baik. 


\section{DAFTAR PUSTAKA}

Arends, R.I. (1997). Classroom instruction and management. New York: McGraw-Hill Company Inc.

Arends, R.I. \& Kilcher, A. (2010). Teaching for student learning: Becoming an accomplished teacher. New York: Routledge.

Barrett, T., Mac Labhrainn, I., \& Fallon, H. (Eds). (2005). Understanding problem based learning dalam Handbook of enquiry \& problem based learning. Galway: CELT.

Delisle, R. (1997). How to use problem-based learning in the classroom. Alexandria, VA: ASCD.

Depdiknas. (2006). Peraturan Pemerintah Nomor 22 Tahun 2006, tentang Standar Isi.

Depdiknas. (2007). Peraturan Menteri Pendidikan Nasional Nomor 41 Tahun 2007, tentang Standar Proses.

Gunter, M. A., Estes, T. H., \& Schwab, J. H. 1990. Instruction: A models approach. Boston: Allyn and Bacon.

Joyce, B., \& Weill, M. (1996). Models of teaching $\left(6^{\text {th }} e d\right)$. Boston: Allyn \& Bacon

Joyce, B., Weill, M., \& Calhoun, E. (2004). Models of teaching $\left(7^{\text {th }} e d\right)$. Boston: Allyn \& Bacon.

Kohlhaas, B. (2011). A study of problem based learning in the middle classroom. Diambil pada tanggal 8 November 2012 dari http://scimath.unl.edu/MIM/files/research/KohlhaasAR_Final_LA.pdf.

Krulik, S \& Rudnick, J. (1995). A new sourcebook for teaching reasoning and problem solving in elementary school. Needham Heights, MA: A Simon \& Schuser company.

Mullis, I.V.S., et.al, (2012). TIMSS 2011 international result in mathematics Chestnut Hill, MA: TIMSS \& PIRLS International Study Center.

Nieveen, N. (1999). Prototyping to reach product quality. Dalam J.V.D Akker et. al (Eds), Design approaches and tools in education and trainning. Netherlands,
Dordsrecht: ICO Cluwer Academic Publisher.

Nieveen, N., McKenney, S., \& Akker, J. V. (2006). Educational design research: the value of variety. In: Van den Akker, J., Gravemeijer, K, McKenney, S. \& Nieveen, N. (Eds). (2006). Educational design research. London: Routledge

NCTM. (2000).Principles and standards for school mathematics. Reston, VA: NCTM

OECD. (2010). Pisa 2009 results: what students know and can do-student performance in reading, mathematics and science (volume I). Diambil pada tanggal 4 Juli 2012, dari

http://dx.doi.org/10.1787/978926409145 0 -en.

Posamentier, A. \& Krulik, S.(1998). Problemsolving strategies for efficient and elegant solutions: A resource for the mathematics teacher. Thousand Oaks, CA: Corwin Press Inc.

Posamentier, A., Smith, B., \& Stepelman, J. (2010). Teaching secondary mathematics: Techniques and enrichment units. Boston: Pearson education Inc.

Polya, G. (1973). How to solve it. Princeton, NJ: Princeton University press.

Pretz, J.E, Naples, J. A, \& Sternberg, J.E. (2003). Recognizing, defining, and representing problems. Dalam Davidson, J.E, \& Strenberg, R.J.(Eds).(2003). The Psychology of Problem Solving. New York: Cambridge University Press

Saifuddin Azwar. (2010). Tes prestasi. Yogyakarta: Pustaka Pelajar.

Smith, M \& Cook, K. (2012). Attendance and achievement in problem-based learning: The value of scaffolding. Interdisciplinary Journal of Problem-based Learning: Vol. 6: Iss. 1, Article 8. Diakses pada 18 Juli 2012 dari http://docs.lib.purdue.edu/ijpbl/vol6/iss1 18.

Zeits, P. (2007). The art and craft of problem solving second edition. New Jersey: John Wiley \& Sons, Inc . 